\title{
Impact of Foreign Direct Investment on Economic Growth of Pakistan
}

\author{
${ }^{1}$ Mahreen Zain, \\ ${ }^{1}$ College of Economics and Management, Nanjing University of Aeronautics and Astronautics, 29 \\ Jiangsu Avenue, Nanjing, China \\ Email:mahreenzain@live.com
}

\begin{abstract}
Foreign direct investment (FDI) is mostly considered as a significant constituent for the overall economic growth of a country. The current research aims to examine the impact of FDI on economic growth of Pakistan. This study uses the time series data from 2000 to 2016. Correlation and Regression analysis in SPSS software were used to analyze the data. The results obtained from the statistical analysis reveal that FDI is positively related to the economic growth of Pakistan.
\end{abstract}

Keywords: FDI, GDP, Pakistan

\section{INTRODUCTION}

Internationally, Foreign Direct Investment (FDI) is considered as one of the most significant elements in economic growth of a country that results in stable financial conditions, higher economic growth and overall well being of community. Over the past years Countries have been pursuing Foreign Direct Investment in order to attain positive impact on revenue generation from financial inflows, technological advancement, improved employment opportunities and managerial skills [1-3]. Whenever there is a shortfall in domestic savings, FDI plays a vital part in the expansion of the economy [4]. Lately, FDI has been an integral part to the country's economy in terms of exposure and technology as well as other resources for developing countries even though their shares in Global economy may be small or even declining [5]. FDI is the vital source of development of developing countries. The important reason why FDI improves the development is through transfer of technology, understanding of knowledge and improved employment level to their host country. One of the most significant reasons is that FDI supports transfer of technology and results in increased employment opportunities to the people of host countries [6]. According to Economists, Foreign Direct Investment through its technological advancement and better style of management put pressure on domestic industries hence making a sense of competition in the domestic economy [7]. Apart from these reasons, FDI brings positive impact on various neglected areas of developing countries like treatment of labor, labor laws and also brings training opportunities resulting in improved standards of finished products. FDI helps the developing economies to depend on their own selves by transferring technology [8]. World investment report (2008) states that, Foreign Direct Investment increases the size of the economy by producing job opportunities, it handovers not only technology but also skills hence result in an increase in productivity level which results in constant development across the developing countries. FDI is also an important source for the 
host country regarding inflow of capital. It helps to grow the economy, helps to grow trade globally, improves management skills and helps to retain the economic development in the host country [9, 10]. There has been a huge hike in the FDI inflow into developing economies in recent two years [11], but research shows that it has not been sufficient enough to stimulate development [12]. It is observed that if the host countries want to get the best result from FDI they must take actions to remove any bureaucratic hurdles that may affect the relationship between foreign investors and the local market [13]. And, also that the host country should focus on resources, that may attract foreign investors to their counties. It is conceived that, FDI is generally desirable for developing economies [14], but still various economists questions its ability to lead economic growth of host countries.

\section{Literature Review:}

Researchers discovered that Foreign Direct Investment has a direct impact on the economic growth [15-17]. It helps the economic development by adding input to the GCF ultimately contributing to information level [18]. Being precise, FDI is understood to have direct impact on the economic growth because FDI is observed as it accompaniments of the domestic investments, and is considered very vital element for capital inflow as well as investment shortages [19]. Further analysis reveals that the positive result on economic growth through FDI is because of knowledge spillovers in transition countries [20, 21]. Without any doubt the key reasons underpinning the growth performance are the efforts in technology and innovation [22]. A study concluded that FDI has positively impacts the host countries which appears differently and depends on the area where investment is made [23]. The impact of FDI is reliant on majorly on the value and size of the investment. The analysis shows that FDI and human capital development together helps the host economy grow bigger [24-26]. Researchers got to the result that FDI is a mixture of capital stock, knowledge and technology, that may help to enhance the existing stock of economy with the help of better management practice, development of skills, giving training to human capital and improved organizational arrangement [27, 28]. Both the studies concluded that FDI positively impacts the economic growth of developing countries. Another research found that panel estimation technique helps to progress the economic conditions of the host country. By allowing the developing countries to exchange with each other, FDI has majorly significant effect on the financial development of a country [29, 30]. Foreign Direct Investment plays a significant role in the financial development of all the countries particularly developing economies. FDI is even considered as the focal point or the engine of the financial development of the country, all the development circles around it $[31,32]$. FDI in good conditions can do wonders. It not only helps to boost the economic growth nonetheless, it helps in reducing the difference between the capital and national savings; it enhances the skill level of the host company and improves the competition in the market [33, 34]. Along with all these positive impacts it also contributes in the technology transfer and helps in good governance [35]. According to researchers, FDI poses a positive effect on the economic development; along with this, helps to enjoy the status of economies of scale, improved human resource, setup and remunerations, and it also plays a role to resolve domestic differences, cooperate vigorously with FDI and enhance financial development in China [36]. According to the empirical analysis by [37], the contribution of Foreign Direct Investment on economic growth in the area is enhanced as a result of development of financial sector. Foreign Direct Investment is vital way for transfer of technology (ToT) to the country where investment is made, helps in growing the economy of the host country [38]; however, the greater productivity of FDI and positive results of the FDI in host country occur to the best if the host country has a least threshold of human resource [39]. [36] states that the effect of Foreign Direct Investment on 
Chinese Economic growth is not that big as one would think of by looking at the estimates. They are less than those numbers. Foreign Direct Investment positively impacts on per person production development [40]. [41] revealed that FDI has a positive and important effect on the goods in high-earning markets, though in high earning economies the impact is insignificant. Impact of FDI, remittances by workers and Official Developers Assistance on the development of economy of emerging economies by the help of time-series data from 1990 to 2006 was studied by [42]. By using the system generalized method approaches, a constructive and important influence of Foreign Direct Investment, the settlements and the ODA on the financial development of the developing countries are observed. During their study, the researchers concluded that the participation of the employee allowances to the financial development is greater than Foreign Direct Investment, and ODA. [34]conducted a study in Ghana and reached to the conclusion that when there is a rise in Foreign Direct Investment, it stimulates progressive GDP progress in the long-term. An empirical assessment was provided by Zhang (2011) and discovered that FDI has appeared to help China's evolution and also promoted earning progression, and this progressive impact of growth appears to increase with the passage of time. Similarly, [41] said there exists a significant correlation among FDI, economic growth and exports. And they also mentioned that the economic development, exports of the country and FDI combines to provide and overall empowerment. With the help of statistical investigation, [42] agreed upon this that instead of gathering out regional investment, FDI has a significant effect on local investments. They also mentioned that in addition to FDI helping in covering lack of investment, it triggered the development of the economy too, via helping local investment in China [42]. [43] initiated an empirical analysis of Bangladesh and stated that there exists a strong connection among three variables, that include trade, growth rate of per capita GDP and FDI. [44] conducted a statistical analysis and concluded that there exists and association among FDI, businesses and growth rate of per person GDP. The results of the analysis further explained that variables like trade and FDI has strong relationship with the growing rate of GDP per person. TFP growth is improved by the influx of FDI to India because of the positive spillovers effects [11]. Foreign Direct Investment stock and output are extensively co-assimilated that was found in study regarding Indian economy in the long run [11]. [32] concluded that FDI has a significant impact on the growth of economy. Consequently, important aspect in the growth of economy of Eurozone is FDI. Similarly FDI has also been important feature for the growth of Malaysian economy FDI because of technological transfer, inflow of capital investment and management of knowledge skills. The research regarding the correlation among FDI and the growth of economy in Malaysia concluded that there exists an important association among growth of economy and influx of Foreign Direct Investment. The study showed FDI has direct positive affect on RGDP [45]. The conclusions from various statistical researches may be summed up as followings; almost all the researchers established that there is a significant influence of FDI on growth of economy. [46] conducted a study using MVGC method in G20 countries from the year 1991 to 2012 and found that there is a strong relationship amid GCF and GDP. Al mutali et al. in the year 2014 lead a study and employed MVGC method and used the data starting from 1980 till 2010 of LACs and he concluded that GCF has a strong effect on GDP. GDP also increases. In the year 2011 a study related to China was done by [47] using MVGC method. They examined the data from 1985 to 2007 and concluded that when there is increase in GDP this has positive impact on GCF also. Similarly, when GDP is decreased GCF will also decrease. A study related to Sub Saharan African countries was conducted by [48] in the year 2001 using Bivariate ganger casuality test method. They took the data from 1985 to 2007 and determined that there is no relationship between GDP and GCF. Either has no effect on each other. Many researches 
have been conducted exploring the association between Inflation and growth in economy. Mundel in the year 1963 was the first economist to present the Idea that increased inflation eventually results in the faster outgrowth of economy [49]. Mundel stated that when there is increase in Inflation Rate, people will have less income to spend which means their real wealth will decrease. Instead of spending they will try to save and thus this will drive down the real interest rate. Higher the savings results in higher capital accumulation and this will eventually result in faster output growth. Tobin [50] was of the view that with the increase in prices i.e. inflation, people tend to substitute money spending into interest earning assets. This ultimately leads to greater capital intensity and leads to economic growth. Hence, according to Tobin inflation and Economic Growth has a direct relationship. Fischer [51] in the year 1993 explained the negative relationship between Inflation and Economic Growth. According to him all these elements like growth, investments, and productivity have negative relationships with inflation.

\section{Conceptual Model}

On the basis of our review of related literature, we propose a model for our study in the following Figure 1, where GDP is the dependent variable and FDI, GCF and IR are the independent variables:

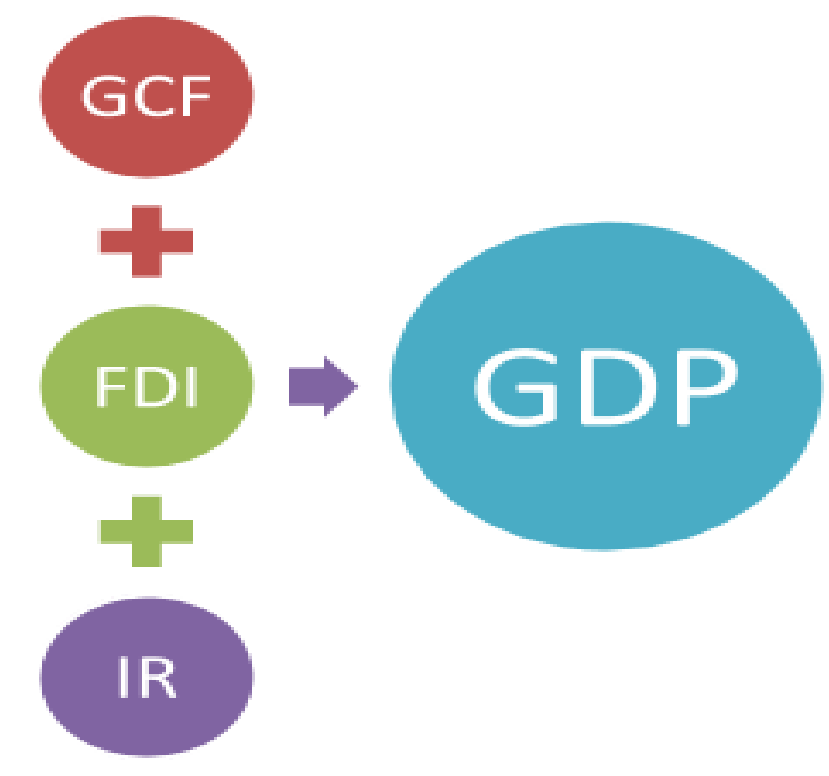

Figure 1: Conceptual Model

\section{Objectives:}

Objective of this study is to explore the relationship between Economic Growth and Foreign Direct Investment in Pakistan. This study will explore whether there is an impact of FDI on overall economic growth of Pakistan or not. Various statistical techniques will be used to investigate this relationship.

\section{Methodology}

\subsection{Data}

Quantitative analysis is done in order to explore the impact of FDI on economic growth of Pakistan. This study uses secondary data collected from World Bank Indicators databank to establish a 
relationship between FDI and Economic Growth in Pakistan. Dependent Variable in this study is Gross Domestic Product (GDP) whereas; the independent variables include FDI, Inflation Rate (IR) and Gross Capital Formation (GCF). The study uses time series data for these variables from year 2000 to 2016. Foreign Direct Investment (FDI) is an investment by an organization established in one country, into an organization of another country. Inflation Rate (IR) is the consistent increase in the prices of goods and services besides declining the buying power of money. IR is represented as yearly percentage. Gross Capital Formation (GCF) includes expenditures on additions to the fixed assets of the economy and net changes in the level of inventories. GCF is represented as percentage of GDP.

\subsection{Model}

Linear Regression analysis technique is utilized using SPSS software to test the relationship between FDI and economic growth in Pakistan. The linear regression model to test the said relationship is given in the Equation (1) below:

$$
G D P=c+\alpha_{1} F D I+\alpha_{2} I R+\alpha_{3} G C F+e
$$

In the above Equation (1), GDP stands for Gross Domestic Product. This is dependent variable here. C represents the constant term, $\alpha_{1}, \alpha_{2}$ and $\alpha_{3}$ are the regression coefficients. FDI (Foreign Direct Investment), IR (Inflation Rate) and GCF (Gross Capital Formation) are independent variables of this model. e stands for error.

\section{Result Analysis and Explanation}

\subsection{Descriptive Statistics}

Given data in Table 1 presents the historical data of the variables under consideration and Table 2 gives the descriptive statistics of these values.

Table 1: Historical Data

\begin{tabular}{|l|c|c|c|c|}
\hline Year & $\begin{array}{c}\text { GDP (Billion } \\
\text { US\$) }\end{array}$ & IR & GCF & \multicolumn{1}{c|}{$\begin{array}{c}\text { FDI (Million US } \\
\text { \$) }\end{array}$} \\
\hline $\mathbf{2 0 0 0}$ & 73.952 & 3.58 & 17.23 & 11 \\
\hline $\mathbf{2 0 0 1}$ & 72.31 & 4.41 & 17.00 & 26 \\
\hline $\mathbf{2 0 0 2}$ & 72.307 & 3.54 & 16.58 & 19 \\
\hline $\mathbf{2 0 0 3}$ & 83.245 & 3.10 & 16.76 & 56 \\
\hline $\mathbf{2 0 0 4}$ & 97.978 & 4.57 & 16.58 & 45 \\
\hline $\mathbf{2 0 0 5}$ & 109.502 & 9.28 & 19.08 & 109 \\
\hline $\mathbf{2 0 0 6}$ & 137.264 & 7.92 & 19.33 & 98 \\
\hline $\mathbf{2 0 0 7}$ & 152.386 & 7.77 & 18.79 & 49 \\
\hline $\mathbf{2 0 0 8}$ & 170.078 & 12.00 & 19.21 & 47 \\
\hline $\mathbf{2 0 0 9}$ & 168.153 & 17.03 & 17.55 & 62 \\
\hline $\mathbf{2 0 1 0}$ & 177.407 & 10.10 & 15.80 & 77 \\
\hline $\mathbf{2 0 1 1}$ & 213.587 & 13.66 & 14.12 & 212 \\
\hline $\mathbf{2 0 1 2}$ & 224.384 & 11.01 & 15.08 & 122 \\
\hline $\mathbf{2 0 1 3}$ & 231.219 & 7.36 & 14.96 & 14.64 \\
\hline $\mathbf{2 0 1 4}$ & 244.361 & 8.62 & \\
\hline
\end{tabular}




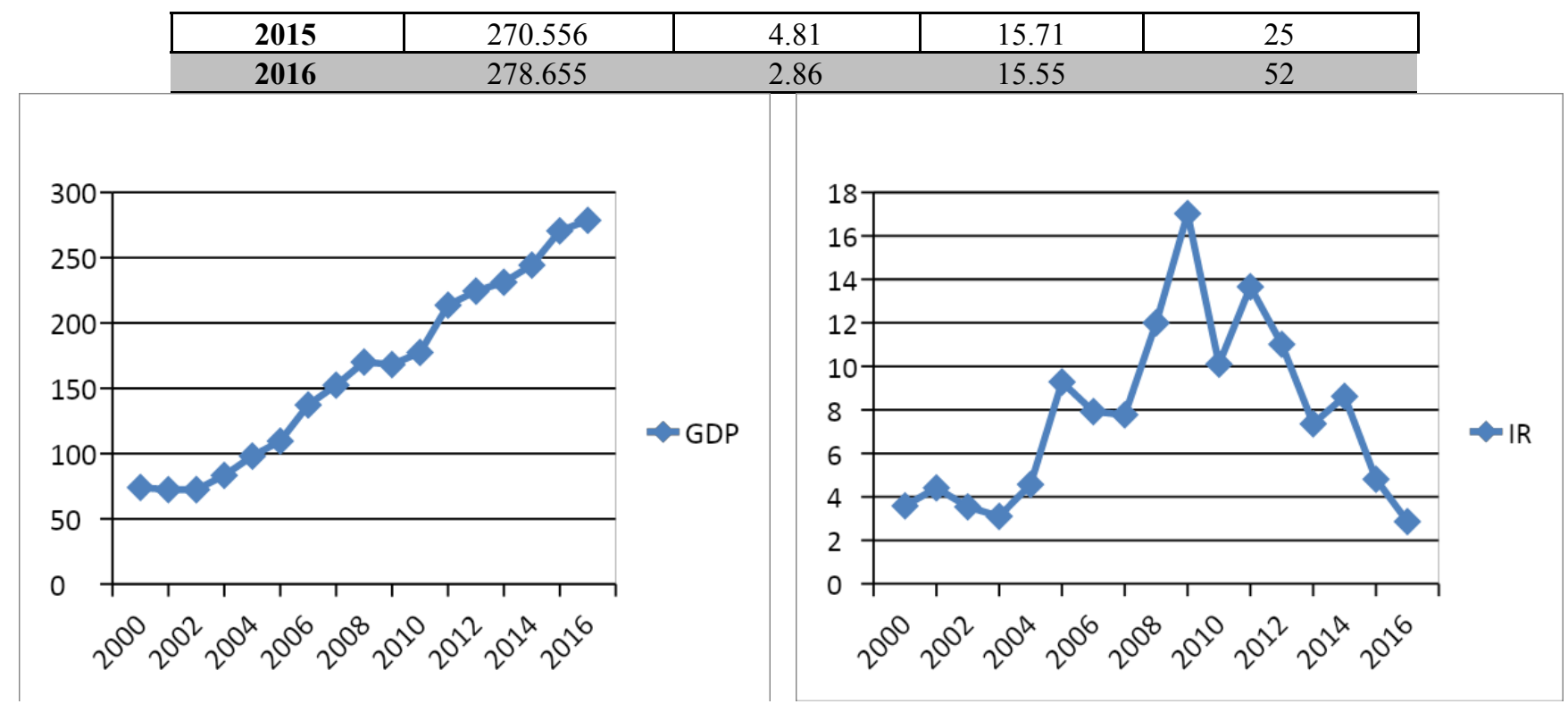

For the understanding and ease of our readers, above data is given in graphical form in figures below:
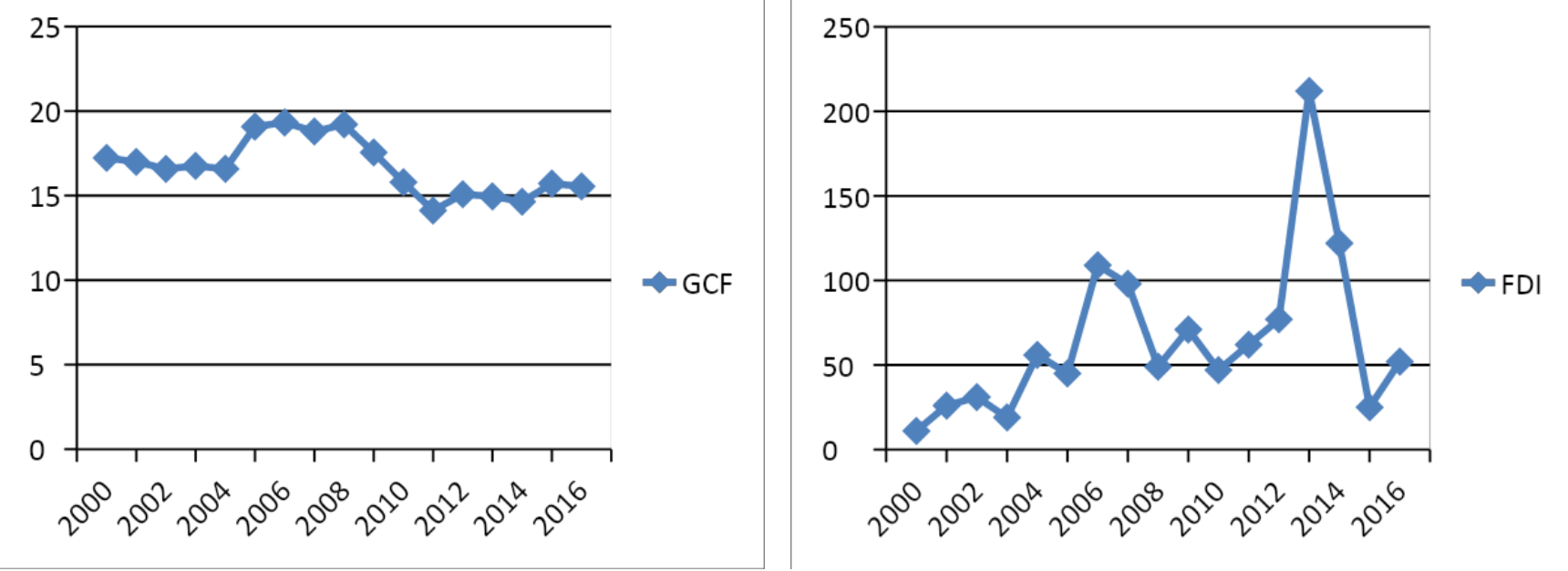

Figure 2: Graphical Representation of Historical Data

Table 2: Descriptive Statistics

\begin{tabular}{|c|c|c|c|c|}
\hline \multicolumn{1}{c}{ Minimum } & Maximum & Mean & \multicolumn{1}{c}{ Std. Deviation } \\
\hline GDP & 72.31 & 278.65 & 1.63 & 71.34 \\
\hline IR & 2.86 & 17.03 & 7.74 & 4.10 \\
\hline GCF & 14.12 & 19.33 & 16.70 & 1.66 \\
\hline FDI & 0.01 & 0.21 & 0.06 & 0.04 \\
\hline
\end{tabular}




\subsection{Normality Test}

Here we will perform Normality test on our variables under consideration. An assessment of the normality of data is a prerequisite for many statistical tests because normal data is an underlying assumption in parametric testing. There are two main methods of assessing normality: graphically and numerically. We will use both the methods to check whether our data is normally distributed or not.

Table 3: Tests of Normality

\begin{tabular}{|l|r|r|r|r|r|r|}
\hline & \multicolumn{3}{|c|}{ Kolmogorov-Smirnov $^{\mathrm{a}}$} & \multicolumn{3}{c|}{ Shapiro-Wilk } \\
\cline { 2 - 7 } & Statistic & \multicolumn{1}{c|}{$\mathrm{df}$} & \multicolumn{1}{c|}{ Sig. } & \multicolumn{1}{c|}{ Statistic } & \multicolumn{1}{c|}{ df } & \multicolumn{1}{c|}{ Sig. } \\
\hline GDP & .128 & 17 & $.200^{*}$ & .925 & 17 & .179 \\
IR & .174 & 17 & .178 & .929 & 17 & .206 \\
GCF & .131 & 17 & $.200^{*}$ & .940 & 17 & .318 \\
FDI & .175 & 17 & .177 & .843 & 17 & .080 \\
\hline
\end{tabular}

*. This is a lower bound of the true significance.

a. Lilliefors Significance Correction

The above table presents the results from two well-known tests of normality, namely the Kolmogorov-Smirnov Test and the Shapiro-Wilk Test. The Shapiro-Wilk Test is more appropriate for small sample sizes ( $<50$ samples), but can also handle sample sizes as large as 2000 . For this reason, we will use the Shapiro-Wilk test as our numerical means of assessing normality. We can see from the above table that all our variables GDP, IR, GCF and FDI are normally distributed. How do we know this? As the Sig. value of the Shapiro-Wilk Test is greater than 0.05 , the data is normal. If it is below 0.05 , the data significantly deviate from a normal distribution.

\subsubsection{Normal Q-Q Plots}

In order to determine normality graphically, we can use the output of a normal Q-Q Plot. If the data are normally distributed, the data points will be close to the diagonal line. If the data points stray from the line in an obvious non-linear fashion, the data are not normally distributed.

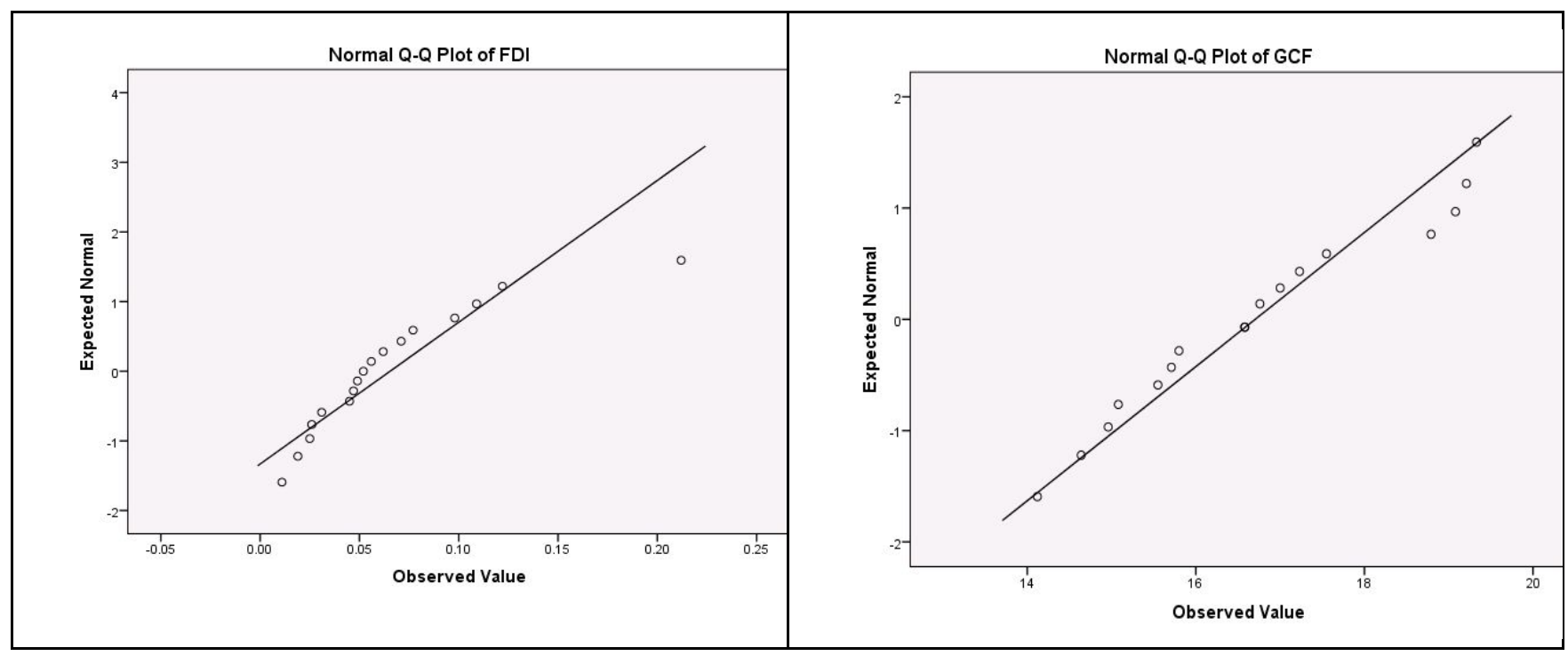




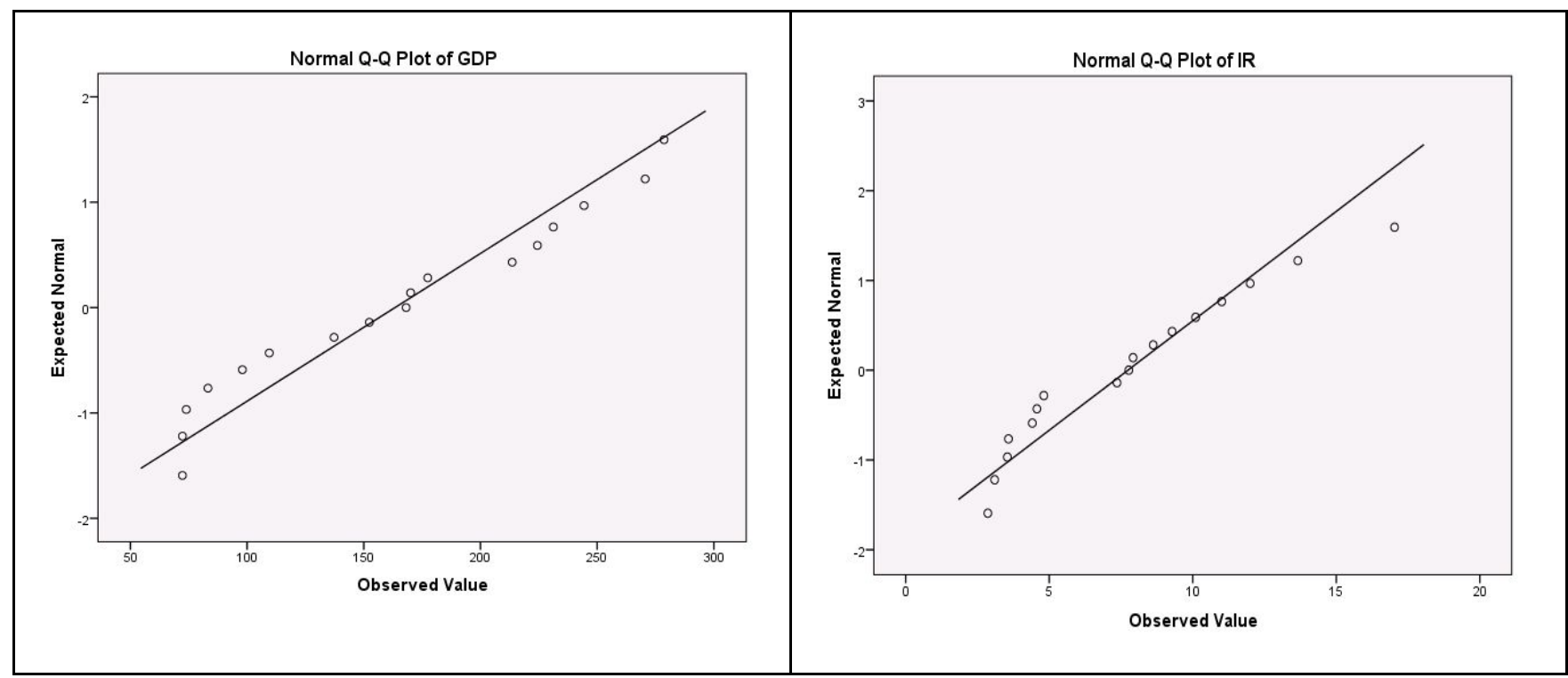

Figure 3: Normal Q-Q Plots

As we can see from the normal Q-Q plots of our variables, the data is normally distributed.

\subsection{Correlation Matrix}

Table 4: Correlation Matrix

\begin{tabular}{|c|c|c|c|c|}
\hline Variables & GDP & FDI & IR & GCF \\
\hline \multirow{3}{*}{ GDP } & 1 & $.435^{*}$ & .282 & $-.541^{*}$ \\
& & .041 & .136 & .012 \\
& 17 & 17 & 17 & 17 \\
\hline \multirow{3}{*}{ FDI } & $.435^{*}$ & 1 & .266 & -.192 \\
& .041 & & .151 & .230 \\
& 17 & 17 & 17 & .045 \\
\hline \multirow{3}{*}{ IR } & .282 & .266 & 1 & .432 \\
& .136 & .151 & 17 & 17 \\
\hline \multirow{3}{*}{ GCF } & 17 & 17 & .045 & 1 \\
& $-.541^{*}$ & -.192 & .432 & 17 \\
\hline
\end{tabular}

*. Correlation is significant at the 0.05 level.

Results presented in the above Table 3 confirm the relationship between GDP and FDI i.e., FDI is positively related to GDP.

\subsection{Regression Analysis}

Regression Analysis has been used here in order to examine the relationship between FDI and Economic Growth (GDP) in Pakistan. Results of the analysis are given in the Table 5: 
Table 5: Model Summary

\begin{tabular}{|c|c|c|c|c|}
\hline Model & R & R Square & Adjusted R Square & Std. Error of the Estimate \\
\hline 1 & $.875^{\mathrm{a}}$ & .855 & .829 & 2.428054 \\
\hline
\end{tabular}

a. Predictors: (Constant), FDI, GCF, IR

The three independent variables include FDI, Inflation Rate (IR), and Gross Capital Formation (GCF). The results indicate that $85.5 \%$ of the variance in economic growth in Pakistan are symbolized by $\mathrm{R}^{2}$ in the table above. In other words, various other variables that could not be incorporated in this model add $14.5 \%$ of the variance to our dependent variable.

Table 6: ANOVA

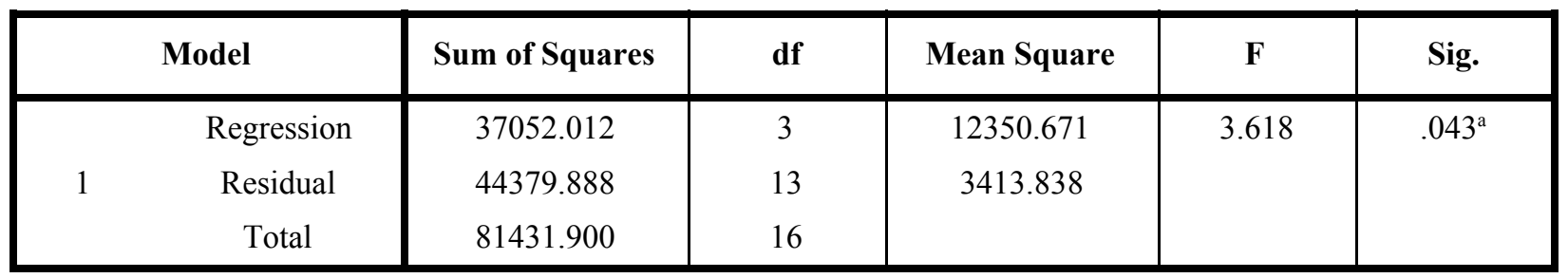

a. Predictors: (Constant), FDI, GCF, IR

b. Dependent Variable: GDP

The findings in the above table show that the significance value is 0.043 which is less than 0.05 , thus the model is statistically significant to forecast how FDI, Gross Capital Formation and Inflation Rate impact the GDP of Pakistan. The current study used Regression Analysis too, in order to explore the impact of unit increase of independent variables on GDP. The findings presented in Table 6 given below show that a unit increase in Inflation Rate results in 4.006 rise in GDP. A unit increase in GCF leads to 21.409 rise in GDP and most importantly, a unit increase in FDI leads to 403.4 rise in GDP.

Table 7: Regression Analysis

\begin{tabular}{|ll|c|c|c|c|c|}
\hline \multicolumn{2}{|c|}{ Model } & \multicolumn{2}{|c|}{ Unstandardized Coefficients } & $\begin{array}{c}\text { Standardized } \\
\text { Coefficients }\end{array}$ & t & \\
\cline { 2 - 4 } & & B & Std. Error & Beta & & \\
\hline \multirow{2}{*}{1} & 463.592 & 155.717 & & 2.977 & .011 \\
& (Constant) & 4.006 & 3.714 & .230 & 1.079 & .300 \\
& IR & 21.409 & 9.017 & .498 & 2.374 & .034 \\
& GCF & 403.444 & 315.657 & .278 & 1.278 & .224 \\
\hline
\end{tabular}

a. Dependent Variable: GDP

Results of this research study are quite interesting and are consistent with the results of other similar studies. 


\section{Conclusion}

Aim of this research was to examine the relationship between foreign direct investment (FDI) and economic growth in Pakistan. The research used data of studied variable from 2000 to 2016. Generally, the statistical analysis shows that there is a positive relationship between economic growth (GDP) and FDI in Pakistan. Various governments over the period of time have been trying to increase FDI in Pakistan that has resulted in overall economic development in the country. It is believed FDI results in transfer of technology (ToT), enhances knowledge through experience of others, educate labor and as a whole, leads to overall development of human skills and technology.

\section{References}

1. Abbes, S.M., et al., Causal interactions between FDI, and economic growth: evidence from dynamic panel co-integration. Procedia Economics and Finance, 2015. 23: p. 276-290.

2. Abdouli, M. and S. Hammami, The impact of FDI inflows and environmental quality on economic growth: An empirical study for the MENA countries. Journal of the Knowledge Economy, 2017. 8(1): p. 254-278.

3. Agrawal, G., Foreign direct investment and economic growth in BRICS economies: A panel data analysis. Journal of Economics, Business and Management, 2015. 3(4): p. 421-424.

4. Ali, M. and I.R. Malik, Impact of Foreign Direct Investment on Economic Growth of Pakistan. 2017.

5. Azam, M. and A.M. Ahmed, Role of human capital and foreign direct investment in promoting economic growth: evidence from Commonwealth of Independent States. International Journal of Social Economics, 2015. 42(2): p. 98-111.

6. Azman-Saini, W., S.H. Law, and A.H. Ahmad, FDI and economic growth: New evidence on the role of financial markets. Economics letters, 2010. 107(2): p. 211-213.

7. Belloumi, M., The relationship between trade, FDI and economic growth in Tunisia: An application of the autoregressive distributed lag model. Economic systems, 2014. 38(2): p. 269-287.

8. Bende-Nabende, A., FDI, regionalism, government policy and endogenous growth: a comparative study of the ASEAN-5 economies, with development policy implications for the least developed countries2018: Routledge.

9. Beugelsdijk, S., R. Smeets, and R. Zwinkels, The impact of horizontal and vertical FDI on host's country economic growth. International Business Review, 2008. 17(4): p. 452-472.

10. Bunte, J.B., et al., Natural resource sector FDI, government policy, and economic growth: Quasi-experimental evidence from Liberia. World Development, 2018. 107: p. 151-162.

11. Chakraborty, C. and P. Nunnenkamp, Economic reforms, FDI, and economic growth in India: a sector level analysis. World development, 2008. 36(7): p. 1192-1212.

12. Dike, C., Effects of Foreign Direct Investment in Sub-Saharan Africa economic growth: evidence from panel data analysis. International Journal of Economics and Financial Issues, 2018. 8(2): p. 255.

13. Fadhil, M.A. and M.K. Almsafir, The role of fdi inflows in economic growth in Malaysia (time series: 1975-2010). Procedia economics and finance, 2015. 23: p. 1558-1566.

14. Gunby, P., Y. Jin, and W.R. Reed, Did FDI really cause Chinese economic growth? A meta-analysis. World Development, 2017. 90: p. 242-255.

15. Hakimi, A. and H. Hamdi, Does corruption limit FDI and economic growth? Evidence from MENA countries. International Journal of Emerging Markets, 2017. 12(3): p. 550-571.

16. Hlavacek, P. and B. Bal-Domanska, Impact of foreign direct investment on economic growth in Central and Eastern European countries. Inžinerinė ekonomika, 2016: p. 294-303.

17. Iamsiraroj, S., The foreign direct investment-economic growth nexus. International Review of Economics \& Finance, 2016. 42: p. 116-133.

18. Iamsiraroj, S. and H. Doucouliagos, Does growth attract FDI?, 2015, Economics Discussion Papers.

19. Karimi, M.S. and Z. Yusop, FDI and economic growth in Malaysia. 2009.

20. Khoshnevis Yazdi, S., K. Homa Salehi, and M. Soheilzad, The relationship between tourism, foreign direct investment and economic growth: evidence from Iran. Current Issues in Tourism, 2017. 20(1): p. 15-26. 


\section{Gyancity Journal of Electronics and Computer Science, Vol.4, No.2, pp. 1-12, September 2019 ISSN: 2446-2918 DOI: 10.21058/gjecs.2019.42004}

21. Madariaga, N. and S. Poncet, FDI in Chinese cities: Spillovers and impact on growth. World Economy, 2007. 30(5): p. 837-862.

22. Mohamed, M.R., K.S.J. Singh, and C.-Y. Liew, Impact of foreign direct investment \& domestic investment on economic growth of Malaysia. Malaysian Journal of Economic Studies, 2017. 50(1): p. 21-35.

23. Naz, S., et al., Moderating and mediating role of renewable energy consumption, FDI inflows, and economic growth on carbon dioxide emissions: evidence from robust least square estimator. Environmental Science and Pollution Research, 2019. 26(3): p. 2806-2819.

24. Ndiaye, G. and H. Xu, Impact of foreign direct investment (FDI) on economic growth in WAEMU from 1990 to 2012. International Journal of Financial Research, 2016. 7(4): p. 33-43.

25. Neequaye, N.A. and R. Oladi, Environment, growth, and FDI revisited. International Review of Economics \& Finance, 2015. 39: p. 47-56.

26. Nistor, P., FDI implications on BRICS economy growth. Procedia Economics and Finance, 2015. 32: p. 981-985.

27. Nwaogu, U.G. and M.J. Ryan, FDI, foreign aid, remittance and economic growth in developing countries. Review of Development Economics, 2015. 19(1): p. 100-115.

28. Omri, A. and A. Sassi-Tmar, Linking FDI inflows to economic growth in North African countries. Journal of the Knowledge Economy, 2015. 6(1): p. 90-104.

29. Rahman, A., Impact of foreign direct investment on economic growth: Empirical evidence from Bangladesh. International Journal of Economics and Finance, 2015. 7(2): p. 178-185.

30. Rehman, N.U., FDI and economic growth: empirical evidence from Pakistan. Journal of Economic and Administrative Sciences, 2016. 32(1): p. 63-76.

31. Pandya, V. and S. Sisombat, Impacts of foreign direct investment on economic growth: Empirical evidence from Australian economy. International Journal of Economics and Finance, 2017. 9(5): p. 121-131.

32. Pegkas, P., The impact of FDI on economic growth in Eurozone countries. The Journal of Economic Asymmetries, 2015. 12(2): p. 124-132.

33. Rjoub, H., et al., The Impact of FDI Inflows on Economic Growth: Evidence from Landlocked Countries in Sub-Saharan Africa. Bilig-Turk DunyasI Sosyal Bilimler Dergisi, 2017. 10(1): p. 153-168.

34. Sakyi, D., R. Commodore, and E.E.O. Opoku, Foreign direct investment, trade openness and economic growth in Ghana: An empirical investigation. Journal of African Business, 2015. 16(1-2): p. 1-15.

35. Sayari, N., R. Sari, and S. Hammoudeh, The impact of value added components of GDP and FDI on economic freedom in Europe. Economic Systems, 2018. 42(2): p. 282-294.

36. Su, Y. and Z. Liu, The impact of foreign direct investment and human capital on economic growth: Evidence from Chinese cities. China Economic Review, 2016. 37: p. 97-109.

37. Silajdzic, S. and E. Mehic, Knowledge spillovers, absorptive capacities and the impact of FDI on economic growth: Empirical evidence from transition economies. Procedia-Social and Behavioral Sciences, 2015. 195: p. 614-623.

38. Simionescu, M., et al., Determinants of economic growth in V4 countries and Romania. Journal of Competitiveness, 2017.

39. Sothan, S., Causality between foreign direct investment and economic growth for Cambodia. Cogent Economics \& Finance, 2017. 5(1): p. 1277860.

40. Stanisic, N., Do foreign direct investments increase the economic growth of Southeastern European transition economies? South-Eastern Europe Journal of Economics, 2015. 6(1).

41. Acaravci, A. and İ. Özturk, Foreign direct investment, export and economic growth: empirical evidence from new eu countries. 2012.

42. Tang, S., E.A. Selvanathan, and S. Selvanathan, Foreign direct investment, domestic investment and economic growth in China: A time series analysis. World Economy, 2008. 31(10): p. 1292-1309.

43. Hussain, M. and M. Haque, Foreign direct investment, trade, and economic growth: An empirical analysis of Bangladesh. Economies, 2016. 4(2): p. 7.

44. Wang, M., Manufacturing FDI and economic growth: evidence from Asian economies. Applied Economics, 2009. 41(8): p. 991-1002.

45. Har, W.-M., K.-L. Teo, and K.-M. Yee, FDI and economic growth relationship: An empirical study on Malaysia. International Business Research, 2008. 1(2): p. 11-18.

46. Pradhan, R.P., et al., Economic growth and the development of telecommunications infrastructure in the G-20 countries: A panel-VAR approach. Telecommunications Policy, 2014. 38(7): p. 634-649. 


\section{Gyancity Journal of Electronics and Computer Science, \\ Vol.4, No.2, pp. 1-12, September 2019 ISSN: 2446-2918 DOI: 10.21058/gjecs.2019.42004}

47. Shuyun, Y. and Y. Donghu, The causality between energy consumption and economic growth in China: using panel method in a multivariate framework. Energy Procedia, 2011. 5: p. 808-812.

48. Easterly, W. and R. Levine, What have we learned from a decade of empirical research on growth? It's Not Factor Accumulation: Stylized Facts and Growth Models. The world bank economic review, 2001. 15(2): p. 177-219.

49. Wyzan, M.L., First Steps Toward Economic Independence: New States of the Postcommunist World1995: Greenwood Publishing Group.

50. Perry, G.L., et al., Inflation in theory and practice. Brookings Papers on Economic Activity, 1980. 1980(1): p. 207-260.

51. Dornbusch, R. and S. Fischer, Moderate inflation. The World Bank Economic Review, 1993. 7(1): p. 1-44. 